\title{
Development of bioactive materials based on bone-bonding mechanism on metal oxides
}

\author{
Toshiki MIYAZAKI ${ }^{\dagger}$ \\ Graduate School of Life Science and Systems Engineering, Kyushu Institute of Technology, \\ 2-4, Hibikino, Wakamatsu-ku, Kitakyushu 808-0196
}

\begin{abstract}
Bioactive ceramics have high biological affinity that enables direct bone-bonding. However they do not have mechanical performances enough to repair bone tissue under loaded conditions. It has been revealed that most materials exhibiting bioactivity form bone-like apatite in body environment. We investigated apatite-forming ability of tantalum- and niobium-based oxide gels in simulated body environment in order to fundamentally clarify chemical structure effective for achieving bioactivity. We found that $\mathrm{Ta}-\mathrm{OH}$ and $\mathrm{Nb}-\mathrm{OH}$ groups on the surfaces of the oxide gels have a potential to form the apatite. On the basis of these findings, we have successfully provided tough tantalum metal with bioactivity by simple $\mathrm{NaOH}$ and heat treatments that form a lot of Ta-OH groups on their surfaces. We also synthesized bioactive organic-inorganic hybrids with flexibility by organic modification of inorganic chemical species with apatite-forming ability. A sequence of material design described above would produce bioactive materials with various mechanical properties.
\end{abstract}

Key-words: Bioactivity, Apatite, Simulated body fluid (SBF), Metal oxide, Functional group, Bioactive metal, Bioactive orga nicinorganic hybrid, Bioactive bone cement, Bone substitutes

\section{Introduction}

Bone defects can be sometimes repaired by own bones extracted from other parts of the patient. However available bone tissue is limited to the only small amounts. Therefore artificial materials to repair the bone defects are needed. However artificial materials implanted into the bone defects are generally encapsulated with a fibrous tissue of collagen. This is a normal reaction for protecting our living body from foreign substances. The implanted material is consequently isolated from the surrounding bone and does not bond to the living bone.

On the other hand, several kinds of ceramics such as $\mathrm{Na}_{2} \mathrm{O}-\mathrm{CaO}-\mathrm{SiO}_{2}-\mathrm{P}_{2} \mathrm{O}_{5}$ glasses named Bioglass ${ }^{\circledR},{ }^{1), 2}$ sintered hydroxyapatite $\left(\mathrm{Ca}_{10}\left(\mathrm{PO}_{4}\right)_{6}(\mathrm{OH})_{2}\right),{ }^{3)}$ glass-ceramic $\mathrm{A}-\mathrm{W}^{4), 5)}$ containing crystalline apatite and wollastonite and so on are found to directly bond to living bone. They are called bioactive ceramics, meaning that they elicit and modulate specific biological activity. ${ }^{6}$ Bone-bonding property of the bioactive ceramics is a quite attractive feature for bone reconstruction, since tight fixation to the surrounding bone can be achieved. However their problem is that they have lower fracture toughness than those of human cortical bone. ${ }^{7)}$ Therefore they cannot be used in highly load-bearing portions such as femoral and tibial bones. Novel design of tough bioactive materials is needed.

It is known that most bioactive ceramics achieve the bonebonding through the formation of low-crystalline apatite layer on their surfaces as shown in Fig. 1. ${ }^{8) 9)}$ This type of apatite has similar composition and structure to natural bone and is often called "Bone-like apatite". Osteoblast can proliferate in preference to fibroblast on the formed apatite, thereby leading to production of bone matrix including col-

\footnotetext{
${ }^{\dagger}$ Corresponding auther: E-mail: tmiya@life.kyutech.ac.jp
}

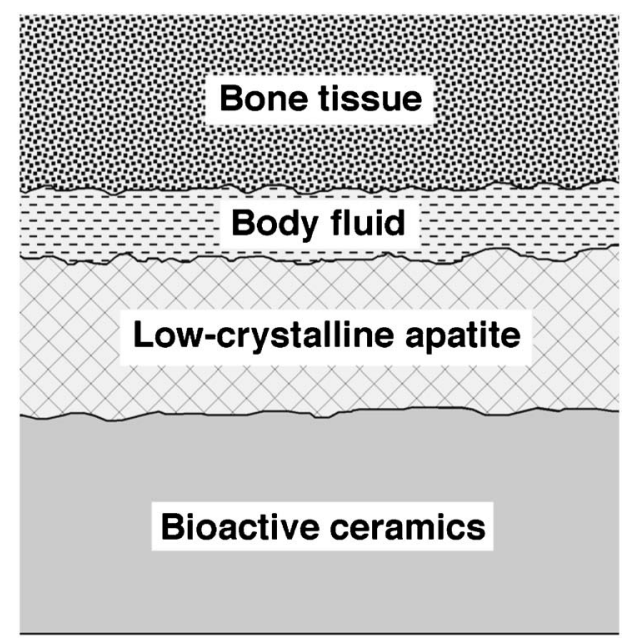

Fig. 1. Bone-bonding mechanism of bioactive ceramics.

lagen fiber and apatite. As a result, the surrounding bone comes into direct contact with the surface apatite on the bioactive material. Afterwards tight chemical bond is produced between the material and the surrounding bone. Consequently the essential requirement for an artificial material to exhibit bioactivity is the formation of bone-like apatite layer on its surface in body environment. The same type of the apatite is formed on the bioactive materials even in an acellular simulated body fluid $(\mathrm{SBF})$ with inorganic ion concentrations nearly equal to those of human extracellular fluid, which was proposed by Kokubo et al. ${ }^{10)-12}$ Bioactivity of an artificial material can be well evaluated in vitro by examining formation of the apatite layer on its 
surface in SBF. ${ }^{13)}$

The key issue for the apatite formation on an artificial material is functional groups abundant on its surface, since the body fluid is already supersaturated with respect to the apatite even under the normal conditions. Fundamental researches have been performed in order to reveal what kind of functional group is effective for the apatite formation in body environment by using sol-gel derived oxide gels, self-assembled monolayer (SAM) and so on. Several functional groups such as $\mathrm{Si}-\mathrm{OH},{ }^{11), 14)} \mathrm{Ti}-\mathrm{OH},{ }^{14), 15)} \mathrm{Zr}-\mathrm{OH},{ }^{16)}$ $\mathrm{COOH},{ }^{17)} \mathrm{PO}_{3} \mathrm{H}_{2},{ }^{17)} \mathrm{SO}_{3} \mathrm{H}^{18), 19)}$ have been found to possess the apatite-forming ability, but $\mathrm{Al}-\mathrm{OH}$ group does not. In addition, release of $\mathrm{Ca}^{2+}$ ions from the materials significantly accelerates the apatite nucleation by increasing degree of supersaturation of the surrounding fluid with respect to the apatite. $^{20)}$

In this study, we review design of bioactive materials with various mechanical performances based on the apatite formation on oxides induced by functional groups, including our research outcomes.

\section{Design of bioactive materials based on tantalum and niobium}

We especially paid our attention on tantalum- and niobium-based materials. Tantalum and niobium metals have high workability due to their excellent malleability and ductility. In addition, they have been known as elements with lower cytotoxicity than titanium. ${ }^{21), 22)}$ Therefore they are clinically used for components of vanadium-free titanium alloys for hip joints. ${ }^{23)}$ Recently carbon porous bodies coated with tantalum have been subjected to clinical use as artificial patella and acetabular cup. ${ }^{24), 25)}$

We synthesized tantalum oxide and niobium oxide hydrogels through sol-gel process and examined their apatite formation in SBF. Pure tantalum oxide and niobium oxide gels formed the apatite on their surfaces in SBF within $7 \mathrm{~d}$ as shown in Fig. 2. ${ }^{26), 27)}$ This means that $\mathrm{Ta}-\mathrm{OH}$ and $\mathrm{Nb}-\mathrm{OH}$ groups are also effective for the heterogeneous apatite nucleation in body environment. The apatite-forming ability of the tantalum oxide gels was enhanced by incorporation with $\mathrm{Na}^{+}$ions to form sodium tantalate. The incorporated $\mathrm{Na}^{+}$ exchanges with $\mathrm{H}_{3} \mathrm{O}^{+}$in SBF to form a lot of $\mathrm{Ta}-\mathrm{OH}$ groups. In addition, increase in $\mathrm{pH}$ due to the ion exchange increases degree of supersaturation with respect to the apatite.

3. Preparation of bioactive metals by surface modification

On the basis of the studies concerning the apatite deposition on the various metal oxide gels, tough metallic materials can be provided with bioactivity through surface modification to form the functional groups with the apatite-forming ability.

Kim et al. proposed simple $\mathrm{NaOH}$ and heat treatments to prepare bioactive titanium metal and its alloys. ${ }^{28)-31 \text { ) }}$ The metals formed amorphous sodium titanate on their surfaces by the treatment and the apatite after subsequent soaking in SBF. Direct bone-bonding was observed when the treated metals were implanted into rabbit tibial bone. ${ }^{32)}$ Titanium metals can be provided with bioactivity by another chemical modification using hydrogen peroxide $\left(\mathrm{H}_{2} \mathrm{O}_{2}\right)$ solution added with tantalum chloride $\left.\left.\left(\mathrm{TaCl}_{5}\right) .33\right)-35\right)$

We applied the $\mathrm{NaOH}$ and heat treatments to the tantalum metal. ${ }^{36), 37)}$ Even untreated tantalum metal formed the

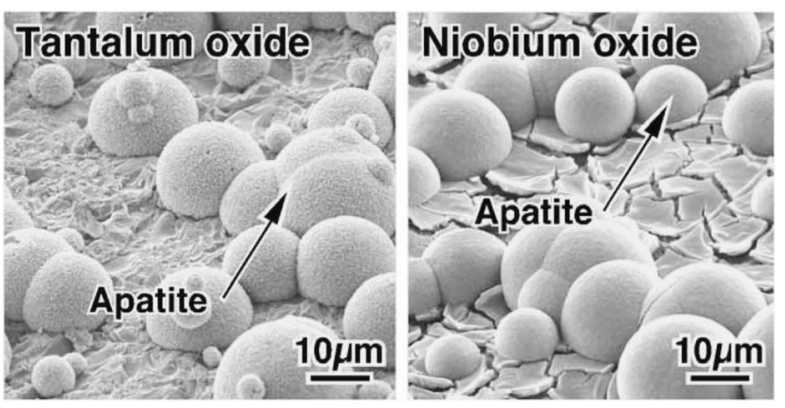

Fig. 2. SEM photographs of the surfaces of tantalum oxide and niobium oxide gels after soaking in SBF for $7 \mathrm{~d}$.
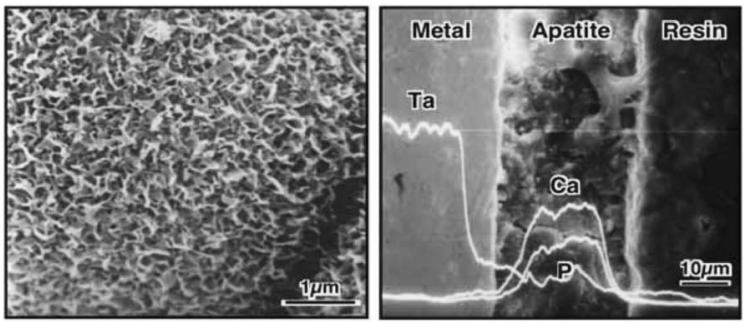

Fig. 3. SEM-EDX profiles of the surface (left) and cross-section (right) of $\mathrm{NaOH}$ - and heat-treated tantalum metals after soaking in SBF for $28 \mathrm{~d}$.

apatite on its surface in SBF after $28 \mathrm{~d}$. However this induction period is too long for practical use. When the metal was treated with $0.5 \mathrm{kmol} \cdot \mathrm{m}^{-3} \mathrm{NaOH}$ aqueous solution at $60^{\circ} \mathrm{C}$ for $24 \mathrm{~h}$ and heated at $300^{\circ} \mathrm{C}$ for $1 \mathrm{~h}$, amorphous sodium tantalate was formed on its surface. It was confirmed by Raman spectroscopy that the sodium tantalate contained chemical structure composed of $\mathrm{TaO}_{6}$ octahedra distorted by $\mathrm{Na}^{+}$similar to the sol-gel-derived sodium tantalate. The treated metal formed the apatite on its surface within $4 \mathrm{~d}$ in SBF. The formed apatite layer is shown in Fig. 3.

Adhesive strength of the apatite layer formed on the tantalum metals in SBF to the substrates was quantitatively measured by tensile test. ${ }^{38)}$ The apatite layer formed on the $\mathrm{NaOH}$ and heat-treated tantalum metal showed higher bonding strength $(14.79 \pm 2.74 \mathrm{MPa})$ than that formed on the untreated metal $(9.08 \pm 1.38 \mathrm{MPa})$. In order to clarify the difference, we precisely characterized surface structure of the tantalum metals by using Auger electron spectroscopy (AES). The measured AES profiles are shown in Fig. 4. The untreated metals steeply decreased $\mathrm{O}$ concentration and steeply increased $\mathrm{Ta}$ concentration with increasing depth from the top surface. On the other hand, $\mathrm{NaOH}$ and heattreated metals gradually decreased $\mathrm{O}$ concentration and gradually increased $\mathrm{Ta}$ and $\mathrm{Na}$ concentrations. This means that the surfaces of the treated metals have a highly graded structure. Such a graded structure maintained even after the apatite deposition in SBF. Enhancement of bonding strength by the $\mathrm{NaOH}$ and heat treatments is attributed to the graded structure produced by the treatments.

When the treated metals are implanted in rabbit tibia, they directly bonded to the living bone through the apatite layer formed in the body as shown in Fig. 5. ${ }^{39)}$ These results indicate that the results on model experiments using sodium 


\section{Untreated}

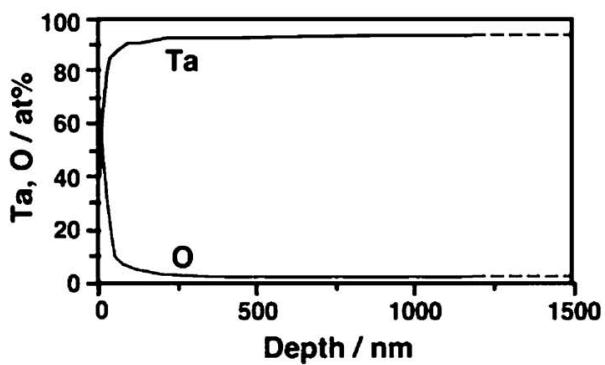

\section{$\mathrm{NaOH}-$ and heat-treated}

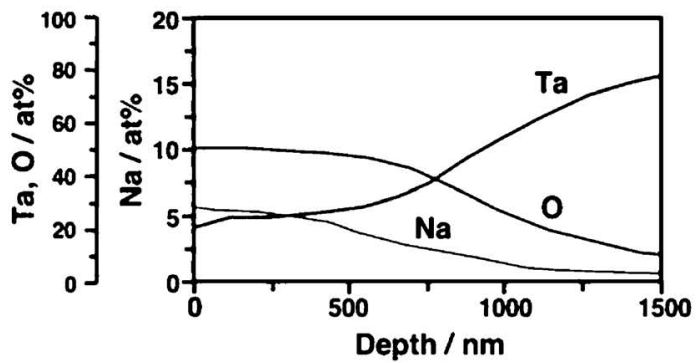

Fig. 4. AES depth profiles of the surfaces of untreated (left) and $\mathrm{NaOH}$ - and heat-treated (right) tantalum metals as a function of depth from the top surface.
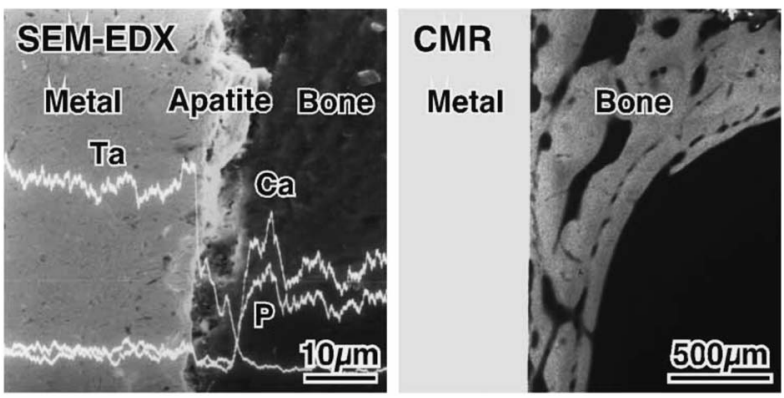

Fig. 5. SEM-EDX profile (left) and contact radio micrograph (CMR, right) of the cross-section of $\mathrm{NaOH}$ - and heat-treated tantalum metals after implantation in rabbit tibia for 16 weeks.

tantalate hydrogels well predict chemical structure effective for achieving bioactivity.

\section{Preparation of bioactive organic-inorganic hybrids}

Even metallic materials have problems to be solved for bone reconstruction. Namely, their Young's modulus is higher than those of human cortical bone. This is liable to prevent load transfer to the surrounding bone and consequent bone regeneration. The phenomena are called stressshielding. Therefore novel bioactive materials with not only fracture toughness but also Young's modulus analogous to natural bone are needed as ideal bone substitutes. It is known that natural bone is a kind of organic-inorganic hybrid where organic collagen and inorganic apatite crystals are three-dimensionally woven at nanometer level. ${ }^{40)}$ These facts bring us an idea that organic-inorganic hybrids where bioactive chemical species are modified with organic polymers can be a candidate for novel bone-repairing materials described above.

Mackenzie et al. reported that organically modified silicates (ORMOSILS) can be synthesized from tetraethylorthosilicate (TEOS) by incorporation of poly (dimethylsiloxane) (PDMS) ${ }^{41)}$ Tsuru et al. revealed that incorporation of calcium nitrate into the ORMOSILS during the sol-gel processing gave the hybrids apatite-forming ability in $\mathrm{SBF}^{42)} \mathrm{Si}-\mathrm{OH}$ groups and $\mathrm{Ca}^{2+}$ ions on ORMOSILS trigger nucleation of the apatite in SBF. Chen et al. modified protocol of the synthesis and obtained TEOS-PDMS-Ca $\left(\mathrm{NO}_{3}\right)_{2}$ hybrids with higher mechanical strength. ${ }^{43)}$

We attempted synthesis of bioactive organic-inorganic

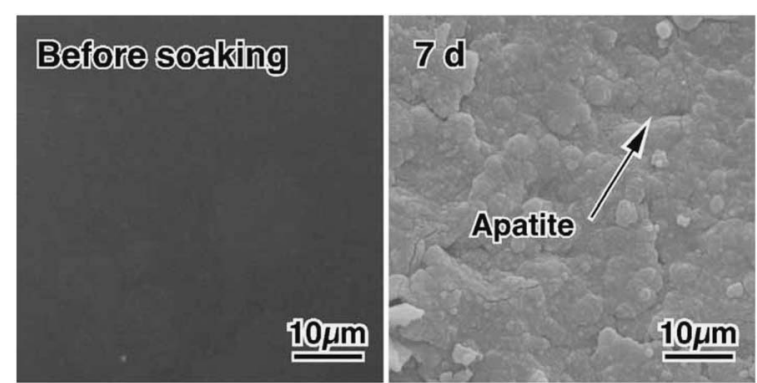

Fig. 6. SEM photographs of the surfaces of MPS-HEMA hybrids before and after soaking in SBF for $7 \mathrm{~d}$.

hybrids by incorporation of methacryloxypropyltrimethoxysilane (MPS, $\left.\mathrm{CH}_{2}=\mathrm{C}\left(\mathrm{CH}_{3}\right) \mathrm{COO}\left(\mathrm{CH}_{2}\right)_{3} \mathrm{Si}\left(\mathrm{OCH}_{3}\right)_{3}\right)$ and calcium chloride $\left(\mathrm{CaCl}_{2}\right)$ into 2-hydroxyethylmethacrylate ( $\left.\mathrm{HEMA}, \quad \mathrm{CH}_{2}=\mathrm{C}\left(\mathrm{CH}_{3}\right) \mathrm{COO}\left(\mathrm{CH}_{2}\right)_{2} \mathrm{OH}\right) .{ }^{44), 45)}$ HEMA has high hydrophilicity and high biological affinity, and is used for medical applications as contact lens and coating agent on artificial blood vessels. ${ }^{46)}$ MPS and HEMA were dissolved in ethanol and heated at $75^{\circ} \mathrm{C}$ for $3 \mathrm{~h}$ with benzoylperoxide as initiator for polymerization of HEMA and MPS. Then the obtained polymer solution was mixed with ethanol solution containing $\mathrm{CaCl}_{2}$. The resultant solutions were cast in polypropylene containers and dried at room temperature for $14 \mathrm{~d}$. Composition of the hybrids was fixed at MPS : HEMA : $\mathrm{CaCl}_{2}=1: 9: 1$ in molar ratio. The hybrids formed the apatite in SBF as shown in Fig. 6.

Various natural and synthetic polymers are available for synthesis of the hybrids. Recent researches have reported preparation of bioactive organic-inorganic hybrids from chitin, ${ }^{47)}$ chitosan, ${ }^{48)}$ starch, ${ }^{49)}$ polycaprolactone ${ }^{50)}$ and poly (vinyl alcohol) (PVA) ${ }^{51)}$ by modification with $\mathrm{Si}-\mathrm{OH}$ and $\mathrm{Ca}^{2+}$ ions. We also found that this type of bioactive organicinorganic hybrids can be prepared from tetraisopropyltitanate (TiPT) that provides Ti-OH group and HEMA by addition of $\mathrm{CaCl}_{2}$. ${ }^{52)}$

Material design utilizing organic-inorganic hybrids can be also applied to preparation of bioactive polymethylmethacrylate (PMMA) bone cements. The cement is composed of PMMA powder added with small amount of polymerization initiator, and setting liquid made from methylmethacrylate (MMA) monomer. ${ }^{53)}$ The powder and the liquid are mixed and injected into the gap between the artificial joints and the 

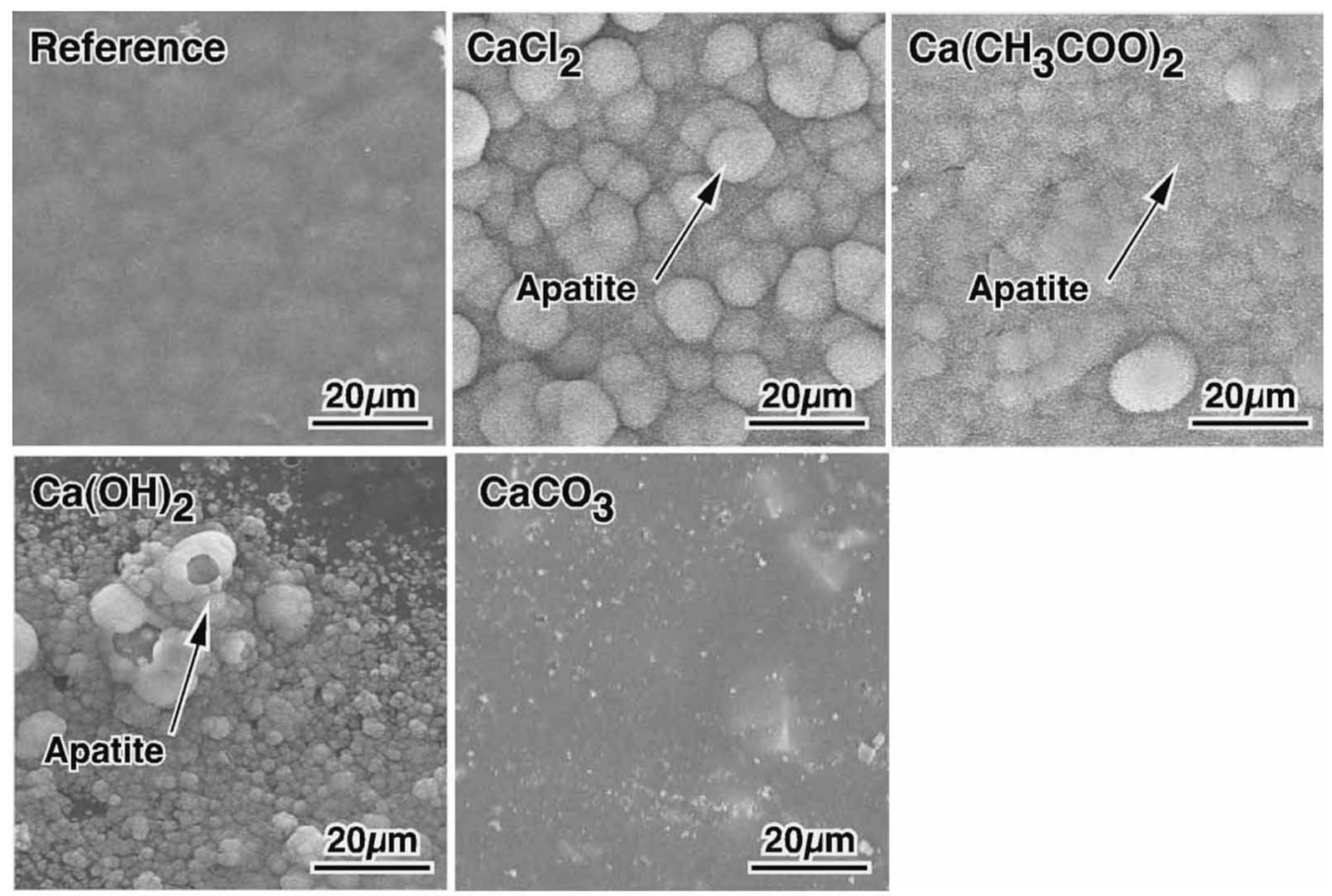

Fig. 7. SEM photographs of the surfaces of PMMA cements which were modified with MPS and different calcium salts after soaking in SBF for $7 \mathrm{~d}$. "Reference" means the cement without modification.

bone. This type of cement is widely used for fixation of the artificial hip joints in orthopedic fields. The problem with the cements is that they do not show bioactivity. Loosening between the bone and cement is liable to occur after a long implantation period.

We prepared novel PMMA cements by chemical modification with $\mathrm{Si}-\mathrm{OH}$ and $\mathrm{Ca}^{2+}$ ions. ${ }^{44), 54), 55)}$ Namely, we added different calcium salts to the powder, and MPS to the liquid. The prepared cements after soaking in SBF are shown in Fig. 7. Those modified with $\mathrm{CaCl}_{2}, \mathrm{Ca}\left(\mathrm{CH}_{3} \mathrm{COO}\right)_{2}$ and $\mathrm{Ca}(\mathrm{OH})_{2}$ formed the apatite on their surfaces, but not that modified with $\mathrm{CaCO}_{3}$. Solubility of the used calcium salts in water increases in the order $\mathrm{CaCO}_{3}<\mathrm{Ca}(\mathrm{OH})_{2}<\mathrm{Ca}\left(\mathrm{CH}_{3}\right.$ $\mathrm{COO})_{2}<\mathrm{CaCl}_{2}$. Addition of calcium salts with high solubility would enhance the apatite formation by release of large amount of $\mathrm{Ca}^{2+}$ ions.

\section{Conclusion}

Bioactive materials with various mechanical properties can be designed through clarification of functional groups effective for apatite formation in body environment and subsequent surface modification of materials with such functional groups. On the basis of this type of material design, we have successfully provided various materials including metals, organic-inorganic hybrids and conventional bone cements with bioactivity.

Acknowledgments The author gratefully acknowledges Prof. Tadashi Kokubo (Chubu University), Prof. Takashi Nakamura (Kyoto University), the late Prof. Hyun-Min Kim (Yonsei University, Korea), Dr. Fumiaki Miyaji (Japan Medical Materials Corporation), Prof. Masao Tanihara (Nara Institute of Science and Technology), Prof. Chikara Ohtsuki (Nagoya University) and Prof. Emeritus Masahiro Ashizuka (Kyushu Institute of Technology) for their discussion and con- tinuous support.

\section{References}

1) L. L. Hench, R. J. Splinger, W. C. Allen and T. K. Greenlee, J. Biomed. Mater. Res. Symp., 2, 117-141 (1972).

2) L. L. Hench, J. Am. Ceram. Soc., 74, 1487-1510 (1991).

3) M. Jarcho, J. Mater. Sci., 11, 2027-2035 (1976).

4) T. Kokubo, M. Shigematsu, Y. Nagashima, M. Tashiro, T. Nakamura, T. Yamamuro and S. Higashi, Bull. Inst. Chem. Res., Kyoto Univ., 60, 260-268 (1982).

5) T. Kokubo, J. Ceram. Soc. Japan, 99, 965-973 (1991).

6) D. F. Williams, "The Williams Dictionary of Biomaterials," Liverpool University Press, Liverpool (1999).

7) “An Introduction to Bioceramics," Ed. by L. L. Hench and J. Wilson, World Scientific, Singapore (1993).

8) H.-M. Kim, J. Ceram. Soc. Japan, 109, S49-S57 (2001).

9) T. Kokubo, H.-M. Kim and M. Kawashita, Biomaterials, 24, 2161-2175 (2003).

10) T. Kokubo, H. Kushitani, S. Sakka, T. Kitsugi and T. Yamamuro, J. Biomed. Mater. Res., 24, 721-734 (1990).

11) S. B. Cho, K. Nakanishi, T. Kokubo, N. Soga, C. Ohtsuki, T. Nakamura, T. Kitsugi and T. Yamamuro, J. Am. Ceram. Soc., 78, 1769-1774 (1995).

12) T. Kokubo and H. Takadama, Biomaterials, 27, 2907-2915 (2006).

13) S. Fujibayashi, M. Neo, H.-M. Kim, T. Kokubo and T. Nakamura, Biomaterials, 24, 1349-1356 (2003).

14) P. Li, C. Ohtsuki, T. Kokubo, K. Nakanishi, N. Soga and K. de Groot, J. Biomed. Mater. Res., 28, 7-15 (1994).

15) M. Uchida, H. M. Kim, T. Kokubo, S. Fujibayashi and T. Nakamura, J. Biomed. Mater. Res. A, 64, 164-70 (2003).

16) M. Uchida, H.-M. Kim, T. Kokubo, F. Miyaji and T. Nakamura, J. Am. Ceram. Soc., 84, 2041-2044 (2001).

17) T. Miyazaki, C. Ohtsuki, Y. Akioka, M. Tanihara, J. Nakao, Y. Sakaguchi and S. Konagaya, J. Mater. Sci. Mater. Med, 14, 569-574 (2003).

18) T. Kawai, C. Ohtsuki, M. Kamitakahara, T. Miyazaki, M. 
Tanihara, Y. Sakaguchi and S. Konagaya, Biomaterials, 25, 4529-4534 (2004).

19) I. B. Leonor, F. Balas, M. Kawashita, R. L. Reis, T. Kokubo and T. Nakamura, J. Mater. Sci.: Mater. Med., 18, 1923-1930 (2007).

20) C. Ohtsuki, T. Kokubo and T. Yamamuro, J. Non-cryst. Solids, 143, 84-92 (1992).

21) Y. Okazaki, S. Asao, S. Rao and T. Tateishi, J. Jpn. Metal, 60, 902-906 (1996).

22) A. Yamamoto, R. Honma and M. Sumita, J. Biomed. Mater. Res., 39, 331-340 (1998).

23) K. Maehara, K. Doi, T. Matsushita and Y. Sasaki, Mater. Trans., 43, 2936-2942 (2002).

24) J. D. Bobyn, G. J. Stackpool, S. A. Hacking, M. Tanzer and J. J. Krygier, J. Bone Joint Surg. (Br.), 81-B, 907-914 (1999).

25) L. D. Zardiackas, D. E. Parsell, L. D. Dillon, D. W. Mitchell, L. A. Nunnery and R. Poggie, J. Biomed. Mater. Res. 58, 180-18 (2001).

26) T. Miyazaki, H.-M. Kim, T. Kokubo, H. Kato and T. Nakamura, J. Sol-gel Sci. Tech., 21, 83-88 (2001).

27) T. Miyazaki, H.-M. Kim, T. Kokubo, C. Ohtsuki and T. Nakamura, J. Ceram. Soc. Japan, 109, 934-938 (2001).

28) H.-M. Kim, F. Miyaji, T. Kokubo, T. Kitsugi and T. Nakamura, J. Biomed. Mater. Res., 32, 409-417 (1996).

29) H.-M. Kim, F. Miyaji, T. Kokubo, T. Kitsugi and T. Nakamura, J. Ceram. Soc. Japan, 105, 111-116 (1997).

30) H.-M. Kim, F. Miyaji, T. Kokubo and T. Nakamura, $J$. Mater. Sci.: Mater. Med., 8, 341-347 (1997).

31) T. Miyazaki, H.-M. Kim, T. Kokubo, C. Ohtsuki and M. Ashizuka, J. Ceram. Soc. Japan Suppl., 112, S848-S852 (2004).

32) W. Q. Yan, T. Nakamura, M. Kobayashi, H. M. Kim, F. Miyaji and T. Kokubo, J. Biomed. Mater. Res., 37, 1-11 (1997)

33) C. Ohtsuki, H. Iida, S. Hayakawa and A. Osaka, J. Biomed. Mater. Res., 35, 39-47 (1997).

34) X. X. Wang, S. Hayakawa, K. Tsuru and A. Osaka, Biomaterials, 23, 1353-1357 (2002).

35) T. Kim, M. Suzuki, C. Ohtsuki, K. Masuda, H. Tamai, E. Watanabe, A. Osaka and Hideshige Moriya, J. Biomed. Mater. Res. Part B: Appl. Biomater., 64B, 19-26 (2003).

36) T. Miyazaki, H.-M. Kim, F. Miyaji, T. Kokubo and T. Nakamura, J. Biomed. Mater. Res., 50, 35-42 (2000).
37) T. Miyazaki, H.-M. Kim, T. Kokubo, F. Miyaji, H. Kato and T. Nakamura, J. Mater. Sci. Mater. Med., 12, 683-687 (2001).

38) T. Miyazaki, H.-M. Kim, T. Kokubo, C. Ohtsuki, H. Kato and T. Nakamura, J. Mater. Sci. Mater. Med., 13, 651-655 (2002).

39) H. Kato, T. Nakamura, S. Nishiguchi, Y. Matsusue, M. Kobayashi, T. Miyazaki, H.-M. Kim and T. Kokubo, $J$. Biomed. Mater. Res. (Appl. Biomater.) , 53, 28-35 (2000).

40) J. B. Park and R. S. Lakes, "Biomaterials; An Introduction (Second Edition)," Plenum Press, New York (1992).

41) Y. Hu and J. D. Mackenzie, J. Mater. Sci., 27, 4415-4420 (1992).

42) K. Tsuru, C. Ohtsuki, A. Osaka, M. Iwamoto and J. D. Mackenzie, J. Mater. Sci. Mater. Med., 8, 157-161 (1997).

43) Q. Chen, F. Miyaji, T. Kokubo and T. Nakamura, Biomaterials, 20, 1127-1132 (1999).

44) C. Ohtsuki, T. Miyazaki and M. Tanihara, Mater. Sci. Eng. $C, 22,27-34$ (2002)

45) T. Miyazaki, C. Ohtsuki and M. Tanihara, J. Nanosci. Nanotech., 3, 511-515 (2003).

46) "Biomaterials science 2nd edition," Ed. by B. D. Ratner, A. S. Hoffman, F. J. Schoen and J. E. Lemons, Elsevier Academic Press, Amsterdam (2004).

47) T. Miyazaki, C. Ohtsuki and M. Ashizuka, J. Biomater. Appl., 22, 71-81 (2007).

48) A. Yamada, K. Tsuru, S. Hayakawa and A. Osaka, "Abstract of the 3rd Asian international Symposium on Biomaterials and Drug Delivery Systems" (2002) p. 279.

49) T. Miyazaki, S. Yasunaga, E. Ishida, M. Ashizuka and C. Ohtsuki, Mater. Trans., 48, 317-321 (2007).

50) S. H. Rhee, Biomaterials, 25, 1167-1175 (2004).

51) C. You, T. Miyazaki, E. Ishida, M. Ashizuka, C. Ohtsuki and M. Tanihara, J. Eur. Ceram. Soc., 27, 1585-1588 (2007).

52) T. Miyazaki, H. Akita, E. Ishida, M. Ashizuka and C. Ohtsuki, J. Ceram. Soc. Japan, 114, 87-91 (2006).

53) K. D. Kühn, "Bone Cements," Springer, Berlin (2000).

54) T. Miyazaki, C. Ohtsuki, M. Kyomoto, M. Tanihara, A. Mori and K. Kuramoto, J. Biomed. Mater. Res., 67A, 1417-1423 (2003).

55) A. Mori, C. Ohtsuki, A. Sugino, K. Kuramoto, T. Miyazaki, M. Tanihara and A. Osaka, J. Ceram. Soc. Japan, 111, 738-742 (2003).

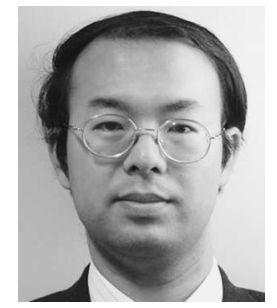

Toshiki Miyazaki is associate professor at Kyushu Institute of Technology. He graduated from Kyoto University in 1996, received his Master of Engineering degree from Kyoto University in 1998, and received his Doctor of Engineering degree from Kyoto University in 2002. He was assistant professor at Nara Institute of Science and Technology (NAIST) from 2000 to 2002 and moved to Kyushu Institute of Technology at 2002. His research topics are development of bioactive materials through surface chemical modification and investigation of apatite mineralization by biomimetic process. 